Article

\title{
The Trace Detection of Nitrite Ions Using Neutral Red Functionalized SH- $\beta$-Cyclodextrin @Au Nanoparticles
}

\author{
Xiaoyang Du ${ }^{1}$, Xiaoxia Zhang ${ }^{1}$, Chunlai Jiang ${ }^{3}$, Weilu Zhang ${ }^{1, *}$ and Lizhu Yang ${ }^{2, *}$ \\ 1 College of Chemistry \& Materials Engineering, Wenzhou University, Wenzhou, Zhejiang 325035, China; \\ 15451283264@stu.wzu.edu.cn (X.D.); 16451283269@stu.wzu.edu.cn (X.Z.) \\ 2 School of Pharmaceutical Sciences, Wenzhou Medical University, Wenzhou, Zhejiang 325035, China \\ 3 The Atmospheric Environment Department, Chinese Academy for Environmental Planning, Beijing 100012, \\ China; jiangcl@caep.org.cn \\ * Correspondence: zwl@wzu.edu.cn (W.Z.); yanglz@wmu.edu.cn (L.Y.); Tel.: +86-138-5771-7511(W.Z.); \\ Tel.: +86-135-8759-9522 (L.Y.)
}

Received: 28 December 2017; Accepted: 21 February 2018; Published: 25 February 2018

\begin{abstract}
A novel fluorescence sensor of NR- $\beta-C D @ A u N P s$ was prepared for the trace detection of nitrite in quantities as low as $4.25 \times 10^{-3} \mu \mathrm{g} \cdot \mathrm{mL}^{-1}$ in an aqueous medium. The fluorescence was due to the host-guest inclusion complexes between neutral red (NR) molecules and gold nanoparticles (AuNPs), which were modified by per-6-mercapto-beta-cyclodextrins (SH- $\beta$-CDs) as both a reducing agent and a stabilizer under microwave radiation. The color of the NR- $\beta-C D @ A u N P s$ changed in the presence of nitrite ions. A sensor was applied to the determination of trace nitrites in environmental water samples with satisfactory results.
\end{abstract}

Keywords: gold nanoparticles; cyclodextrin; neutral red; nitrite ions; fluorescence sensor; trace detection

\section{Introduction}

Gold nanoparticles (AuNPs) have important applications in the fields of nanoscience and nanotechnology because of their unique optical, electronic, and catalytic properties [1]. First, the distance-dependent surface plasmon resonance (SPR) band of AuNPs makes them vital units for establishing assembly/disassembly modulated colorimetric sensors [2,3]. Second, the high specific surface areas of AuNPs result in their surfaces being modified with multiple ligands [4]. Meanwhile, AuNPs are an ideal energy acceptor in structured fluorescence resonance energy transfer systems (FRET) due to their high extinction coefficient [5-7]. Additionally, the major advantage of AuNPs-based sensors is that the molecular recognition can appear as a color change, which can be easily observed by the naked eye [8]. To date, AuNPs have been applied to the fabrication of assembly/disassembly modulated colorimetric sensors [9], as well as various types of optical [10,11] and electrochemical [12,13] sensors and biosensors [14]. Among them, the interactions of AuNPs with macrocycles such as cyclodextrins, calixarenes, and cucurbiturils [15-17] have received considerable attention for their special and potential properties, for example, the application of resveratrol-stabilized AuNPs in the anticancer field [18].

As a well-known molecular receptor, $\beta$-cyclodextrin $(\beta-C D)$ can form host-guest inclusion complexes with a wide variety of organic, inorganic, and biologic guest molecules in their hydrophobic cavities $[19,20]$. In parallel, $\beta-C D$ is water-soluble and environmentally friendly, and is useful in improving the dispersibility of the functional materials [21-24]. On the basis of host-guest interactions, these complexes have been well applied to self-assembly, drug/gene delivery, separation, and sensing applications $[15,25]$. Considering the unique topological structures that macrocyclic supramolecules possess, several novel 3452 properties and corresponding new applications may be presented when 
$\beta-C D$ is attached to the surfaces of AuNPs [26]. For example, $\beta$-CD-capped AuNPs assembled on ferrocene-functionalized indium tin oxide surfaces were applied to enhance the voltammetric analysis of ascorbic acid [27].

The concentration of $\mathrm{NO}_{2}{ }^{-}$is one of the most important parameters in water quality [28]. The maximum allowable amount of nitrite in drinking water is $100 \mathrm{ng} \cdot \mathrm{mL}^{-1}$, according to the regulation of the European Community [29]. The rapid detection of trace concentrations of $\mathrm{NO}_{2}{ }^{-}$ in water bodies is essential $[30,31]$. Many analytical methods for the trace detection of nitrite and nitrate have been reported, including colorimetric methods [32,33], fluorometric methods [34], and electrochemical methods $[35,36]$. However, these methods have limitations such as poor sensitivity, anti-interference, and the use of expensive experimental apparatus. The chemiluminescent methods have proven to be more sensitive and selective in the measurement of nitrite and nitrate [37-42]. Some of the typical methods are summarized in Table S1 (see Supplementary materials). Neutral red (NR) exists in two different prototropic forms in aqueous solutions, namely, the cationic/protonated $\left(\mathrm{NRH}^{+}\right)$ and neutral (NR) forms, depending on the $\mathrm{pH}$ of the solution. NR is a type of dye containing a primary amine structure, which can interact with $\mathrm{NO}_{2}{ }^{-}$and lead to fluorescence quenching. Meanwhile, it has been reported that hydroxyls in the cavities of $\beta-\mathrm{CD}$ form inclusion complexes with the nitrogen atoms on heterocyclic molecules of NR $[43,44]$.

In this paper, a sensitive sensor is established for the trace detection of $\mathrm{NO}_{2}{ }^{-}$in water because of the observation of a color change. Ultraviolet-visible spectroscopy (UV-Vis), transmission electron microscopy (TEM), and Fourier transform infrared spectroscopy (FT-IR) spectra are explored to understand the quenching interaction and corresponding binding forces. AuNPs modified by SH- $\beta-\mathrm{CD}$ were used as both the reducing agent and stabilizer in this method. Monodispersed $\beta$-CD@AuNPs with $10 \mathrm{~nm}$ diameters are synthesized in an eco-friendly way, which is different than previous approaches used for the fabrication of $\beta-C D @ A u N P s[45,46]$. No harsh reagents are used in this method. NR- $\beta$-CD@AuNPs were synthesized by host-guest recognition between the $\beta$-CD@AuNPs and NR. The host was $\beta-C D @ A u N P s$, and the guest was NR. The detection of nitrite ions was traced by the diazonium reaction of $\mathrm{NO}_{2}{ }^{-}$and the primary amine of NR. The fabrication of the NR- $\beta-C D @ A u N P$ sensor and nitrite detection are shown in Scheme 1.

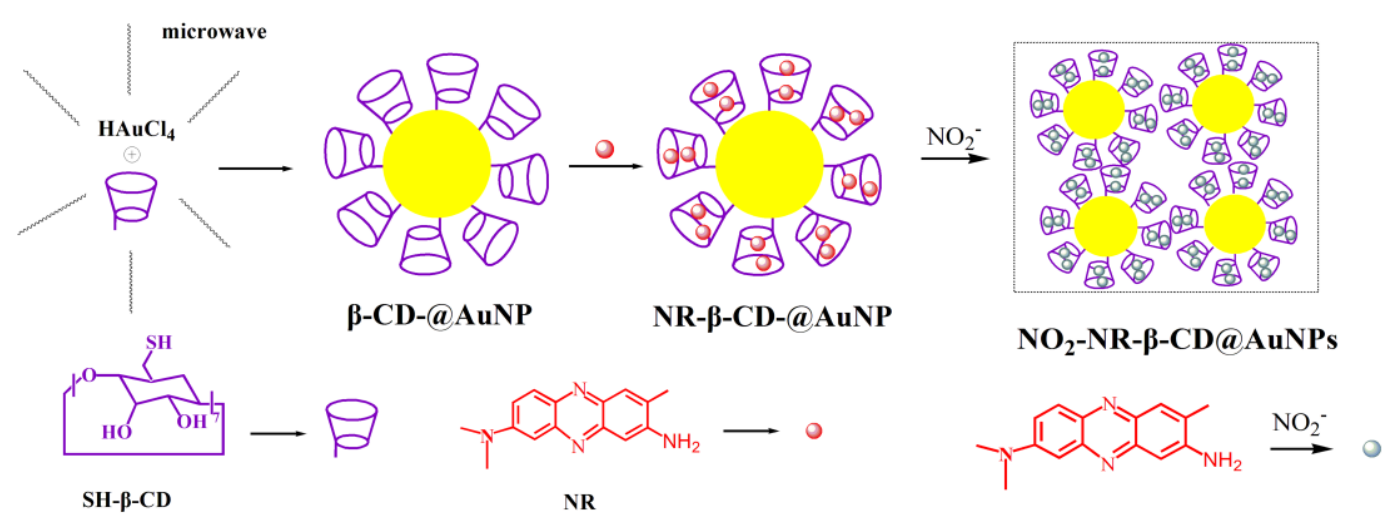

Scheme 1. Schematic representation of the fabrication of the NR- $\beta$-CD@AuNP sensor and nitrite detection.

\section{Materials and Methods}

\subsection{Reagents and Materials}

Chloroauric acid trihydrate $\left(\mathrm{HAuCl}_{4} \cdot 3 \mathrm{H}_{2} \mathrm{O}, 99.99 \%\right)$, sodium nitrite $\left(\mathrm{NaNO}_{2}, 99.0 \%\right)$, hydrochloric acid $(\mathrm{HCl}, 36 \%)$, borax $\left(\mathrm{Na}_{2} \mathrm{~B}_{4} \mathrm{O}_{7} \cdot 10 \mathrm{H}_{2} \mathrm{O}, 99.0 \%\right)$, sodium bicarbonate $\left(\mathrm{Na}_{2} \mathrm{CO}_{3}, 99.0 \%\right)$, neutral red (NR, $4 \%$ in water), sodium bicarbonate $\left(\mathrm{NaHCO}_{3}, 99.0 \%\right)$, disodium hydrogen phosphate $\left(\mathrm{Na}_{2} \mathrm{HPO}_{4}\right.$, 99.0\%), sodium sulfate $\left(\mathrm{Na}_{2} \mathrm{SO}_{4}, 99.0 \%\right)$, sodium chloride $(\mathrm{NaCl}, 99.0 \%)$, sodium fluoride $(\mathrm{NaF}, 99.0 \%)$, 
sodium dihydrogen phosphate $\left(\mathrm{NaH}_{2} \mathrm{PO}_{4}, 99.0 \%\right)$, and sodium nitrate $\left(\mathrm{NaNO}_{3}, 99.0 \%\right)$ were purchased from Aladdin Industrial Corporation (Shanghai, China). Per-6-mercapto-beta-cyclodextrin (SH- $\beta-C D$, 99.0\%) was purchased from Shandong Binzhou Zhiyuan Bio-Technology Co., Ltd (Shandong, China). Other reagents were of analytical grade and directly used without further purification. All solutions were prepared using ultra-pure water $(=18.20 \mathrm{M} \Omega \cdot \mathrm{cm})$.

\subsection{Apparatus}

The morphology and the size of products were obtained from TEM, JEM-2100 (JEOL, Tokyo, Japan). The absorption spectra were obtained using a UV-2600 spectrophotometer (SHIMADZU, Tokyo, Japan). The fluorescence spectra were obtained using a FluoroMAX-4-TCSPC detector (HORIBA Jobin Yvon, Paris, France). The AuNPs were prepared with the microwave reactor Discover CEM (CEM, Matthews, NC, USA).

\subsection{Preparation of the $S H-\beta-C D$ Functionalized $A u N P s(\beta-C D @ A u N P s)$}

The $\beta$-CD@AuNPs were synthesized by the $\mathrm{SH}-\beta-\mathrm{CD}$ reduction of $\mathrm{HAuCl}_{4}$. Briefly, $0.010 \mathrm{~g}$ $\mathrm{HAuCl}_{4} \cdot 3 \mathrm{H}_{2} \mathrm{O}$ and $15.0 \mathrm{mg} \mathrm{SH}-\beta-\mathrm{CD}$ were dissolved in $30.0 \mathrm{~mL}$ ultra-pure water using an ultrasonication for $5 \mathrm{~min}$. The mixture was stirred for $3 \mathrm{~min}$ at $120^{\circ} \mathrm{C}$ under microwave radiation of $150 \mathrm{~W}$. A suspension of the $\beta$-CD@AuNPs characterized by a wine-red color was finally obtained and stored at $4{ }^{\circ} \mathrm{C}$. The reaction was different from previous approaches for the preparation of $\beta$-CD@AuNPs because no sodium borohydride was used.

\subsection{Preparation of Fluorescence Dye-Incorporated SH- $\beta-C D$ Functionalized Gold Nanoparticles} (NR- $\beta-C D @ A u N P s)$

In a typical experiment, $5 \mathrm{~mL}$ of a $\mathrm{NaHCO}_{3}$-borax buffer solution and $5 \mathrm{~mL}$ of $\mathrm{NR}\left(5 \times 10^{-6} \mathrm{~mol} \cdot \mathrm{L}^{-1}\right)$ were added into $5 \mathrm{~mL}$ of the $\beta$-CD@AuNP solution, and the solution was stirred in a dark environment at room temperature for $80 \mathrm{~min}$. A solution of NR- $\beta-C D @ A u N P s$ was obtained, which became orange-red.

\subsection{Detection of Nitrite Ions}

$\mathrm{NaNO}_{2}(14.99 \mathrm{mg})$ was dissolved in ultra-pure water to prepare a $100.0 \mathrm{mg} \cdot \mathrm{L}^{-1}$ standard solution, which was diluted to the desired concentrations for further use. $\mathrm{A} \mathrm{NaNO}_{2}$ standard solution $(2.1 \mathrm{~mL})$ and a $\mathrm{HCl}\left(1.50 \mathrm{mg} \cdot \mathrm{L}^{-1}\right)$ solution $(0.2 \mathrm{~mL})$ were added sequentially into a 5 -mL colorimetric tube, followed by the addition of $0.7 \mathrm{~mL}$ of the above-prepared NR- $\beta$-CD@AuNP solution. Fluorescence spectra were obtained after $5 \mathrm{~min}$.

\subsection{Detection of Nitrite Ions in Real Samples}

The water samples were obtained from local ponds and Oujiang river (Wenzhou City, China). Then, the samples underwent filtration and centrifugal separation, after which the NR- $\beta$-CD@AuNPs were added to the samples, and then the fluorescence spectra were collected.

\section{Results}

\subsection{Characterization of the $\beta-C D @ A u N P s$}

The UV-Vis spectra of the $\beta-C D @ A u N P s$ are shown in Figure 1A. An absorption band at $526 \mathrm{~nm}$ indicated the typical feature of the AuNPs and the localized surface plasmon resonance of the dispersed $\beta-C D @ A u N P s$. The absorption peak was sharper than that prepared from $\mathrm{HAuCl}_{4}$ reduced by sodium citrate (see Supplementary materials, Figure S1A). The color also exhibited a slight variation that can be seen from the inner illustration of Figure 1A. The different colors of the AuNPs obtained using SH- $\beta-C D$ and sodium citrate may be due to their different sizes and morphologies, as mentioned in Reference [47]. When the surfaces of the AuNPs were decorated with SH- $\beta$-CD molecules, they could be employed as scaffolds and energy acceptors for fluorescent sensing by host-guest interactions. The binding 
of SH- $\beta-C D$ with AuNPs was verified by comparing the FT-IR spectra between the SH- $\beta-C D$ s and $\beta-C D @ A u N P s$, as shown in Figure 1B. The spectrum of SH- $\beta-C D(b)$ had a band at $1647 \mathrm{~cm}^{-1} \mathrm{that}^{-}$ corresponds to the stretching vibration peak of $-\mathrm{C}=\mathrm{O}$. The bands at 1157 and $938 \mathrm{~cm}^{-1}$ correspond to the stretching vibration peak of -C-O. The peak at $1590 \mathrm{~cm}^{-1}$ of the spectrum of $\beta-C D @ A u N P s(a)$ is the stretching vibration peak of $-\mathrm{C}=\mathrm{O}$. The two peaks at approximately 1155 and $1028 \mathrm{~cm}^{-1}$ correspond to the stretching vibration peak of -C-O. Moreover, the S-H stretching band at $2576 \mathrm{~cm}^{-1}$ of SH- $\beta-C D$ (b) disappeared in the FT-IR spectrum of $\beta-C D @ A u N P s(a)$, which proved the formation of an Au-S bond, according to References [8] and [26].

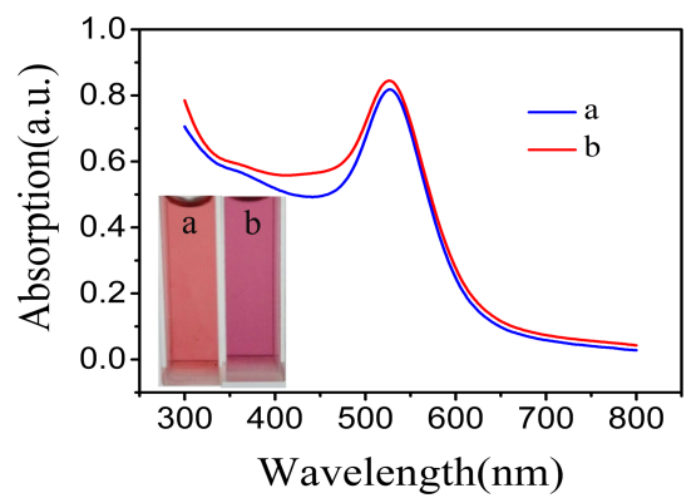

(A)

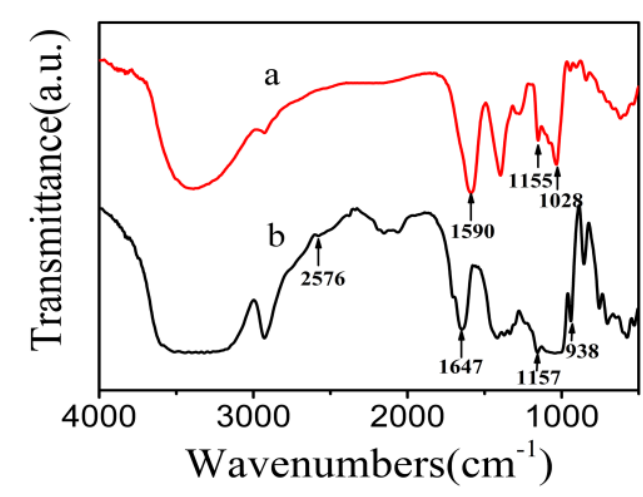

(B)

Figure 1. (A) UV-Vis spectra of the $\beta$-CD@AuNPs (a) and AuNPs (b); (B) FT-IR spectra of the $\beta-C D @ A u N P s(a)$ and SH- $\beta-C D(b)$.

To further confirm their nanostructure and atomic composition, the $\beta$-CD@AuNPs were analyzed by transmission electron microscopy (TEM), and the images are shown in Figure 2. The $\beta$-CD@AuNPs were nearly spherically shaped with an average size of $10 \mathrm{~nm}$. Energy dispersive spectrometry (EDS) element mappings of $\beta-C D @ A u N P s$ are also shown in Figure 2 using different colors, in which the red and green areas correspond to elemental $\mathrm{Au}$ and $\mathrm{S}$, respectively.

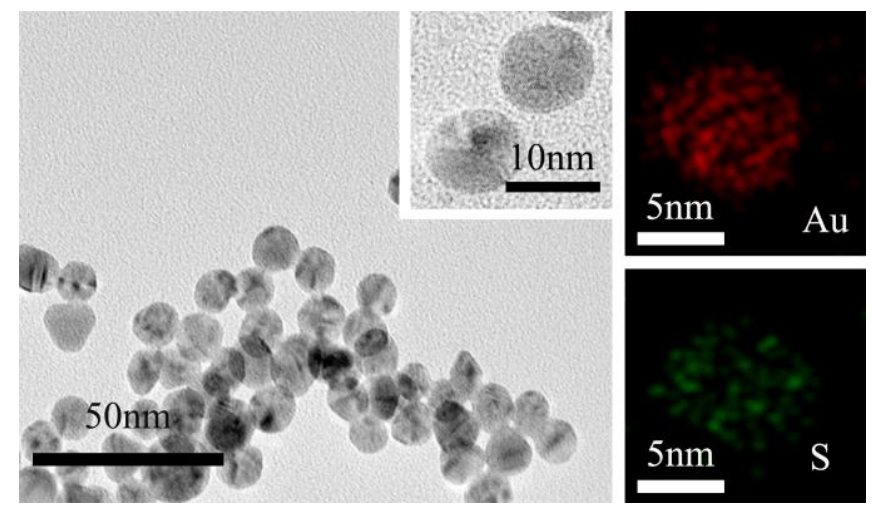

Figure 2. TEM images and energy dispersive spectrometry (EDS) element mappings of the $\beta-C D @ A u N P s ;$ the red and green colors correspond to elemental Au and S, respectively.

The preparation of AuNPs from $\mathrm{HAuCl}_{4}$ reduced by sodium citrate was also tested in this paper. Additionally, the morphological characteristics of the TEM images are shown in Figure S1B (see Supplementary materials). Several of the nanoparticles were approximately $10 \mathrm{~nm}$ in size and some exhibited an irregular spherical shape. 


\subsection{Characterization of the NR- $\beta-C D @ A u N P s$}

To demonstrate the potential application of NR- $\beta-C D @ A u N P s$ during the trace detection of $\mathrm{NO}_{2}{ }^{-}$in water, the host-guest recognition of $\beta-C D @ A u N P s$ and NR molecules was studied in this paper. Nitrogen heterocyclic molecules reacted with the hydroxyls of $\beta-C D$ when the guest molecules of NR entered the cavities of the $\beta$-CD@AuNPs, used as the host molecules. The AuNPs were designed especially for their signal amplification in this paper. Therefore, a sensor of NR- $\beta$-CD@AuNPs exhibits a higher sensitivity than a sensor of both NR and NR- $\beta-C D$ (see Supplementary materials, Figure S2A). The fluorescence of the NR- $\beta$-CD@AuNPs were gradually quenched with the addition of the host molecules of $\beta$-CD@AuNPs, and ultimately a stable quenching rate was attained when the volume of the $\beta$-CD@AuNPs was $5 \mathrm{~mL}$. The fluorescence spectra are shown in Figure 3A. The relationship between fluorescence intensity and the volume of the $\beta$-CD@AuNPs solution is shown in Figure 3B. The fluorescence intensity of the NR- $\beta$-CD@AuNPs gradually decreased with an increase in $\beta$-CD@AuNPs. The fluorophores entered into the macrocyclic cavities of the $\beta$-CD@AuNPs for structure matching by host-guest interactions. As a consequence, the quenching efficiency achieved a constant value when the volume of the $\beta$-CD@AuNPs solution reached $5 \mathrm{~mL}$. The average size of the NR- $\beta$-CD@AuNPs was $10 \mathrm{~nm}$ (see inserted TEM image in Figure 3B) and the dispersion of size was even and comparable to that of the $\beta$-CD@AuNPs (shown in Figure 2).

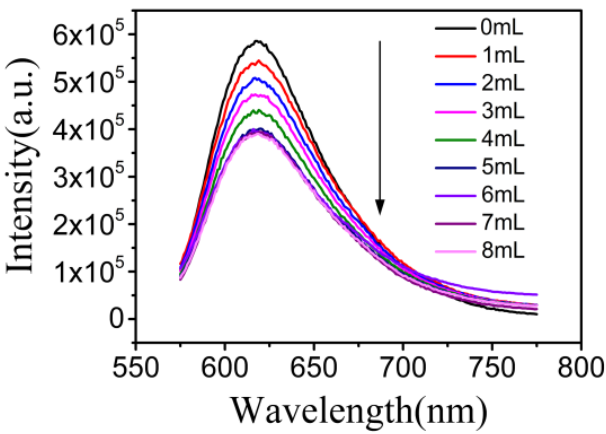

(A)

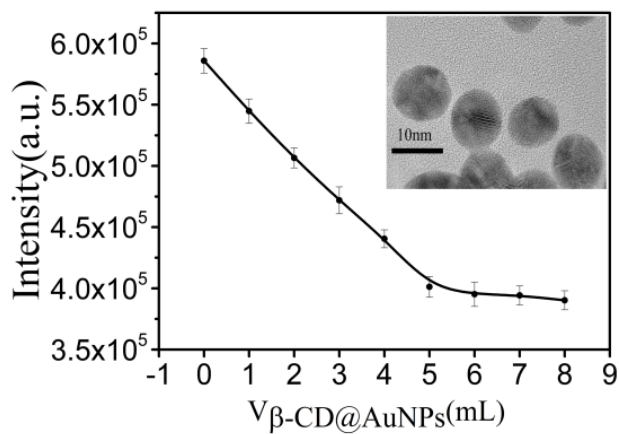

(B)

Figure 3. (A) Fluorescence spectra of the NR- $\beta$-CD@AuNPs when the volume of $\beta$-CD@AuNPs was 1 , $2,3,4,5,6,7$, and $8 \mathrm{~mL}$. (B) Plots of the NR- $\beta$-CD@AuNPs fluorescence intensities versus the volume of the $\beta-C D @ A u N P s$ with error bars. Inserted image: TEM image of the NR- $\beta$-CD@AuNPs.

The energy of NR was transferred to the AuNPs through $\beta-C D$ during the synthesis of NR- $\beta$-CD@AuNPs [47]. The quenching constant of $\mathrm{K}_{\mathrm{sv}}$ was $1.68 \times 10^{4} \mathrm{~L} \cdot \mathrm{mol}^{-1}$, which was calculated according to the Stern-Volumer equation [48]:

$$
F / F_{0}=1+K_{S V}[Q]
$$

where $F_{0}$ and $F$ are the fluorescence intensities before and after the addition of $\beta$-CD@AuNPs, respectively; $K_{\mathrm{SV}}$ is the static quenching constant; and [Q] is the concentration of $\beta$-CD@AuNPs.

\subsection{Effect of $p H$ on the Fluorescence Property of the NR- $\beta-C D @ A u N P s$}

The prototropic equilibrium shifted from $\mathrm{NRH}^{+}$to NR in the cavity of $\mathrm{SH}-\beta-\mathrm{CD}$ with a change in the solution $\mathrm{pH}$. $\mathrm{NRH}^{+}$was the main form in an acidic aqueous solution with an absorption peak at $530 \mathrm{~nm}$, and NR was the dominant form in a weakly alkaline media with an absorption peak at $450 \mathrm{~nm}$. The fluorescence spectra of the NR- $\beta-C D @ A u N P s$ were changed with various $\mathrm{pH}$ values accordingly to the reaction between the NR- $\beta-C D @ A u N P s$ and $\mathrm{NO}_{2}{ }^{-}$, which could be clearly monitored by the fluorescence spectra. A diazonium group was formed by the selective reaction between $\mathrm{NO}_{2}{ }^{-}$and the primary amine group of NR, which is unstable in weakly acidic and alkaline media, and rapidly 
converted to another stable form with nitrogen $\left(\mathrm{N}_{2}\right)$ released [49]. On the other hand, diazonium salts easily react with surplus aromatic amine groups in $\mathrm{NR}$ with a deficiency of $\mathrm{NO}_{2}{ }^{-}$during the diazotization reaction. As a result, the acid-base properties of the solution and the concentrations of $\mathrm{NO}_{2}{ }^{-}$were the principal factors for the diazo coupling reaction.

Experiments were carried out to explore the fluorescence properties of NR- $\beta-C D @ A u N P s$ at different $\mathrm{pH}$ values in the range of 2-9. The effect of $\mathrm{pH}$ on the excitation spectra of the NR- $\beta$-CD@AuNPs is shown in Figure 4A. The excitation peak appeared at $448 \mathrm{~nm}$ when the solution was weakly alkaline, which corresponds to the neutral form of NR. Another excitation peak appeared at $532 \mathrm{~nm}(\mathrm{pH}=7)$ due to the increasing amount of the protonated form of $\mathrm{NRH}^{+}$. Only the excitation peak at $532 \mathrm{~nm}$ remained when the aqueous solution was acidic. The corresponding emission peak (red line) shifted from 621 to $627 \mathrm{~nm}$ with an increase in the fluorescence intensity in Figure 4B. Because the ground-state $\mathrm{pK}_{\mathrm{a}}$ value was 6.8 of $\mathrm{NR}$ in water, the critical point of the excitation peak at $\mathrm{pH}=7$ appeared. Changing from rose-red to purple, the colors of the NR- $\beta$-CD@AuNPs were different in weakly alkaline and acidic solutions, as shown in the inserted image of Figure 4B. The TEM image in Figure 4C shows the morphology of the NR- $\beta$-CD@AuNPs at $\mathrm{pH} 5$, which is similar to that at $\mathrm{pH} 9$. In the presence of $\mathrm{NO}_{2}{ }^{-}$, the fluorescence intensity of the solution clearly decreased compared to that of the NR- $\beta-C D @ A u N P s$ solution, as shown in Figure 4C. The NR- $\beta$-CD@AuNPs can detect trace amounts of $\mathrm{NO}_{2}{ }^{-}$in acidic to weakly alkaline aqueous solutions. It was demonstrated that NR- $\beta$-CD@AuNPs have a broad detection range. The relatively wide detection range of NR- $\beta$-CD@AuNPs may have contributed to the structure of $\beta$-CD@AuNPs.

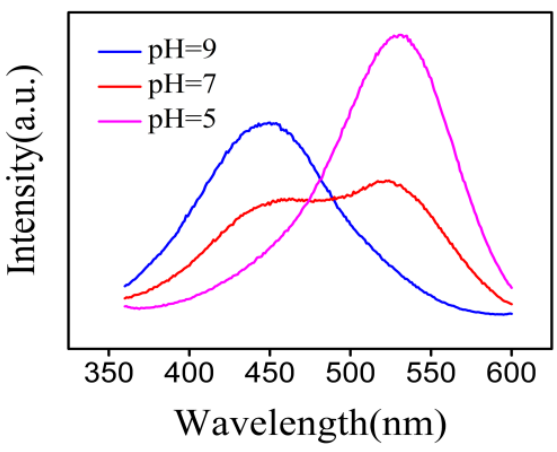

(A)

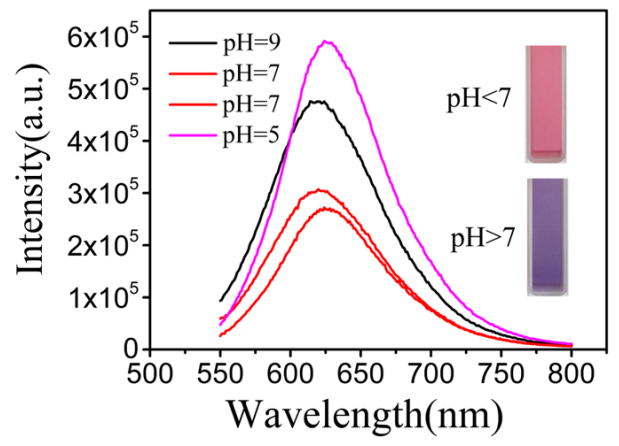

(B)

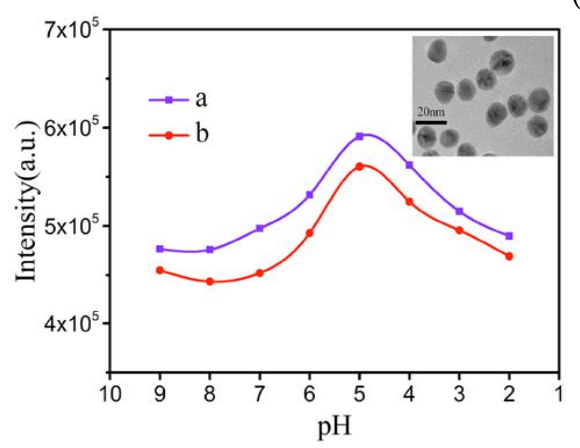

(C)

Figure 4. (A) Excitation spectra of the NR- $\beta-C D @ A u N P s$ at $\mathrm{pH}$ values of 9, 7, and 5; (B) Emission spectra of the NR- $\beta$-CD@AuNPs at $\mathrm{pH}$ values of 9, 7, and 5; (C) Fluorescence intensity of the NR- $\beta-C D @ A u N P s(a)$ and the NR- $\beta-C D @ A u N P s$ in the presence of $\mathrm{NO}_{2}{ }^{-}\left(100 \mu \mathrm{g} \cdot \mathrm{L}^{-1}\right)(\mathrm{b})$; Inserted image: TEM image of the NR- $\beta-C D @ A u N P s$ at a $\mathrm{pH}$ value of 5 .

\subsection{The Detection of $\mathrm{NO}_{2}{ }^{-}$in an Aqueous Solution}

To investigate the detection sensitivity of NR- $\beta-\mathrm{CD} @ A u N P$ s to $\mathrm{NO}_{2}{ }^{-}$in broad ranges, experiments were designed in both weakly alkaline and acidic media. When the solution was weakly alkaline, the fluorescence intensity of the NR- $\beta$-CD@AuNPs at $623 \mathrm{~nm}$ was clearly gradually quenched with an 
increasing concentration of $\mathrm{NO}_{2}^{-}\left(\left[\mathrm{NO}_{2}{ }^{-}\right]\right)$, as shown in Figure 5A. A linear relationship $\left(\mathrm{R}^{2}=0.998\right)$ was obtained between the fluorescence intensity and $\left[\mathrm{NO}_{2}{ }^{-}\right]$in the range of $0.0-0.9 \mu \mathrm{g} \cdot \mathrm{mL}^{-1}$. When $\left[\mathrm{NO}_{2}{ }^{-}\right]$exceeded $0.9 \mu \mathrm{g} \cdot \mathrm{mL}^{-1}$, the rate of fluorescence quenching reached $100 \%$, and the color changed accordingly. The regression equation was $\mathrm{F}=473893-539242 \mathrm{C}$, where $\mathrm{F}$ represents the fluorescence intensity of the solution, and $\mathrm{C}$ represents $\left[\mathrm{NO}_{2}{ }^{-}\right]$(see Supplementary materials, Figure S3A). The detection limit was as low as $5.78 \times 10^{-3} \mu \mathrm{g} \cdot \mathrm{mL}^{-1}$, which was calculated as follows: the blank solution was measured 11 times, and its standard deviation was multiplied by 3 and divided by the slope of the linear relationship. The fluorescence quenching was static because the non-fluorescent diazonium groups were produced, and $K_{\mathrm{sv}}$ was $9.8 \times 10^{4} \mathrm{~L} \cdot \mathrm{mol}^{-1}$, as calculated by Equation (1). The experiments under acidic conditions were performed in the same way as those performed under weakly alkaline conditions, apart from the employed $\mathrm{pH}$ values, and the results are shown in Figure 5B. The regression equation was F = 574156 - 673222C (see Supplementary materials, Figure S3B), and the detection limit was $4.25 \times 10^{-3} \mu \mathrm{g} \cdot \mathrm{mL}^{-1}$, which is better than that of the weakly alkaline conditions. The $K_{\mathrm{sv}}$ was $2.1 \times 10^{5} \mathrm{~L} \cdot \mathrm{mol}^{-1}$, as determined by Equation (1).

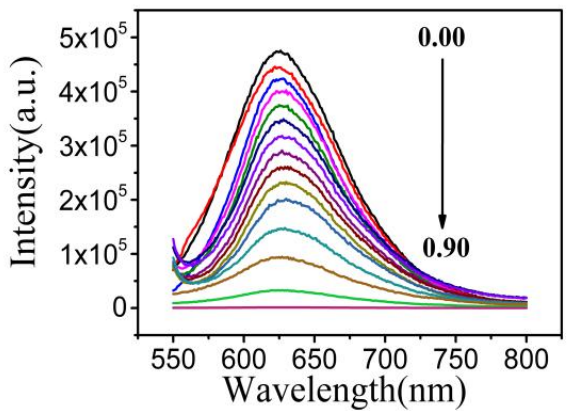

(A)

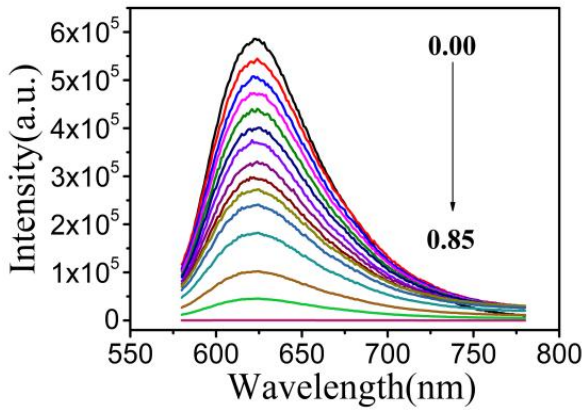

(B)

Figure 5. (A) Emission spectra of the NR- $\beta-C D @ A u N P s$ in the presence of different $\left[\mathrm{NO}_{2}{ }^{-}\right]$ concentrations, including $0,0.05,0.10,0.15,0.20,0.25,0.30,0.35,0.40,0.45,0.50,0.60,0.70,0.80$, and $0.90 \mu \mathrm{g} \cdot \mathrm{mL}^{-1}$ under a weakly alkaline medium; (B) Emission spectra of the NR- $\beta$-CD@AuNPs in the presence of different $\left[\mathrm{NO}_{2}{ }^{-}\right]$concentrations including $0,0.05,0.10,0.15,0.20,0.25,0.30,0.35,0.40$, $0.45,0.50,0.60,0.70,0.80$, and $0.85 \mu \mathrm{g} \cdot \mathrm{mL}^{-1}$ under an acid medium.

As shown in Figure 6, the colorimetric response was recorded. It was obvious that the color changed from light purple to light blue, and could be observed by the naked eye, when $\left[\mathrm{NO}_{2}{ }^{-}\right]$was approximately $0.30 \mu \mathrm{g} \cdot \mathrm{mL}^{-1}$.

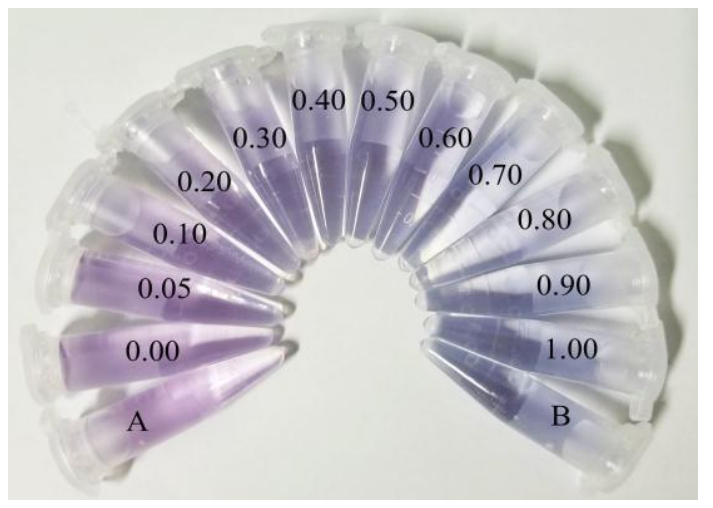

Figure 6. Photograph of the NR- $\beta-C D @ A u N P s$ in the presence of different $\left[\mathrm{NO}_{2}{ }^{-}\right]$concentrations including $0,0.05,0.10,0.20,0.30,0.40,0.50,0.60,0.70,0.80,0.90$, and $1.00 \mu \mathrm{g} \cdot \mathrm{mL}^{-1} ; \mathrm{A}: 0 \mu \mathrm{g} \cdot \mathrm{mL}^{-1}$ of $\left[\mathrm{NO}_{2}{ }^{-}\right]$and competing ions; and $\mathrm{B}: 1.00 \mu \mathrm{g} \cdot \mathrm{mL}^{-1}$ of $\left[\mathrm{NO}_{2}{ }^{-}\right]$and competing ions. 
Both NR and NR- $\beta-C D$ could be used to detect $\mathrm{NO}_{2}{ }^{-}$based on our results (see Supplementary materials, Figure S4), and the detection limit was $0.56 \mu \mathrm{g} \cdot \mathrm{mL}^{-1}$ and $5.6 \times 10^{-2} \mu \mathrm{g} \cdot \mathrm{mL}^{-1}$, respectively. The solutions must be under a strongly acidic condition of $\mathrm{pH} 1$ for higher detection limits. The NR- $\beta$-CD@AuNP sensor exhibited a good sensitivity of $5.78 \times 10^{-3} \mu \mathrm{g} \cdot \mathrm{mL}^{-1}$.

The diazonium group between $\mathrm{NO}_{2}{ }^{-}$and the primary amine group of NR was more stable in an acid solution [49]. Compared with other sensors [50,51], this sensor displayed a wide detection range and good sensitivity. Some of the typical methods are summarized in Table S1 (see Supplementary materials).

After reacting with $\mathrm{NO}_{2}{ }^{-}$, the product of $\mathrm{NO}_{2}-\mathrm{NR}-\beta-\mathrm{CD} @$ AuNPs was analyzed by UV-Vis spectra (Figure 7). The UV-Vis spectrum of the NR- $\beta-C D @ A u N P s$ (a) had two absorption bands at $520 \mathrm{~nm}$ and $450 \mathrm{~nm}$, which correspond to the two states of NR. There were two new absorption bands appearing at $583 \mathrm{~nm}$ and $349 \mathrm{~nm}$ for the $\mathrm{NO}_{2}-\mathrm{NR}-\beta-\mathrm{CD} @ A u N P$. The color was also different when the NR- $\beta-C D @ A u N P s$ reacted with $\mathrm{NO}_{2}{ }^{-}$, as shown in Figure 7.

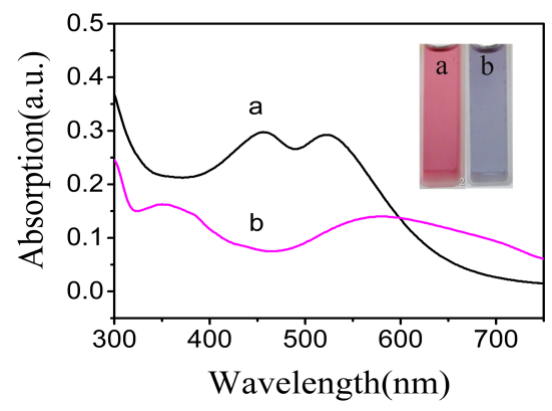

Figure 7. UV-Vis spectra of the NR- $\beta-C D @ A u N P s(a)$ and $N_{2}-N R-\beta-C D @ A u N P s(b)$.

\subsection{Selectivity}

A 100-fold concentration of the other common ions were selected as competing ions in order to demonstrate the selectivity of this sensor, including $\mathrm{Cl}^{-}, \mathrm{CO}_{3}{ }^{2-}, \mathrm{HCO}_{3}{ }^{-}, \mathrm{F}^{-}, \mathrm{SO}_{4}{ }^{2-}, \mathrm{H}_{2} \mathrm{PO}_{4}{ }^{-}, \mathrm{HPO}_{4}{ }^{2-}$, and $\mathrm{NO}_{3}{ }^{-}$. Meanwhile, $\left[\mathrm{NO}_{2}{ }^{-}\right]$of $0.35 \mu \mathrm{g} \cdot \mathrm{mL}^{-1}$ was measured as the control group. As shown in Figure 8, the fluorescence quenching only occurred at $623 \mathrm{~nm}$ in the presence of $\mathrm{NO}_{2}{ }^{-}$, even though it contained other ions. These results emphasized the high selectivity of the fluorescence sensor for the trace detection of $\mathrm{NO}_{2}{ }^{-}$.

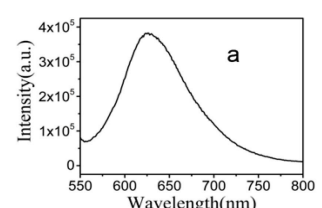

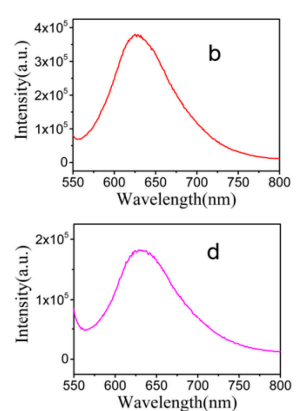

(A)

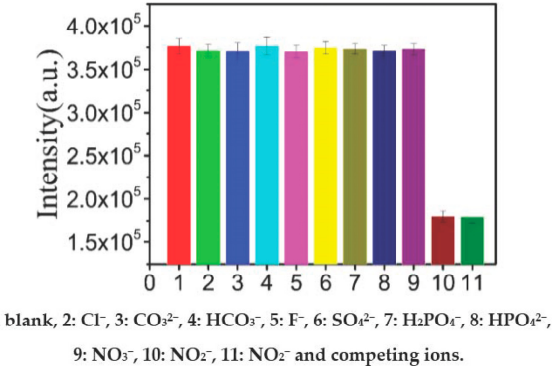

(B)

Figure 8. (A) Fluorescence spectra of the (a) NR- $\beta$-CD@AuNPs; (b) NR- $\beta$-CD@AuNPs and competing ions $\left(\mathrm{Cl}^{-}, \mathrm{CO}_{3}{ }^{2-}, \mathrm{HCO}_{3}{ }^{-}, \mathrm{F}^{-}, \mathrm{SO}_{4}{ }^{2-}, \mathrm{H}_{2} \mathrm{PO}_{4}{ }^{-}, \mathrm{HPO}_{4}{ }^{2-}\right.$ and $\left.\mathrm{NO}_{3}{ }^{-}\right)$; (c) NR- $\beta-\mathrm{CD} @ A u N P s$ and $\mathrm{NO}_{2}{ }^{-}$; and (d) NR- $\beta-C D @ A u N P s, \mathrm{NO}_{2}{ }^{-}$and competing ions. (B) Fluorescence intensity of the NR- $\beta$-CD@AuNPs and 1: blank, 2: $\mathrm{Cl}^{-}, 3: \mathrm{CO}_{3}{ }^{2-}, 4: \mathrm{HCO}_{3}{ }^{-}, 5: \mathrm{F}^{-}$, 6: $\mathrm{SO}_{4}{ }^{2-}, 7: \mathrm{H}_{2} \mathrm{PO}_{4}{ }^{-}, 8: \mathrm{HPO}_{4}{ }^{2-}$, 9: $\mathrm{NO}_{3}{ }^{-}, 10: \mathrm{NO}_{2}{ }^{-}, 11: \mathrm{NO}_{2}{ }^{-}$and competing ions. 


\subsection{Application of $\mathrm{NO}_{2}{ }^{-}$Detection in Real Samples}

The sensor was used to detect $\mathrm{NO}_{2}{ }^{-}$in the waters of a local river or pond to determine the realistic efficiency of an NR- $\beta-C D @ A u N P$ sensor. Recovery experiments were carried out on samples by adding nitrite ion standards [52]. The data are listed in Table 1, and the method has a recovery of 98.6-102.5\% with a relative standard deviation (RSD) of less than $3 \%$. The result indicated that the sensor was reliable for detecting $\mathrm{NO}_{2}{ }^{-}$in outdoor waters. It is confirmed that the NR- $\beta-\mathrm{CD} @ A u N P s$ could be available for the detection of $\mathrm{NO}_{2}{ }^{-}$in real samples.

Table 1. Results of the detection of nitrite ions in river (1) and pond (2) water $(n=6)$.

\begin{tabular}{cccccc}
\hline Samples & Content $\left(\mathrm{NO}_{\mathbf{2}}{ }^{-}, \boldsymbol{\mu g} \cdot \mathbf{m L}^{-\mathbf{1}}\right)$ & Added $\left(\mathrm{NO}_{\mathbf{2}}{ }^{-}, \boldsymbol{\mu g} \cdot \mathbf{m L}^{-\mathbf{1}}\right)$ & Found $\left(\mathrm{NO}_{\mathbf{2}}{ }^{-}, \boldsymbol{\mu g} \cdot \mathrm{mL}^{-\mathbf{1}}\right)$ & Recovery $(\%)$ & $\mathbf{R S D}(\%)$ \\
\hline 1 & $0.23 \pm 0.01$ & 0.10 & $0.33 \pm 0.01$ & $101.00 \pm 1.5$ & $1.20 \pm 0.5$ \\
2 & $0.32 \pm 0.02$ & 0.10 & $0.42 \pm 0.01$ & $99.80 \pm 1.2$ & $2.10 \pm 0.7$ \\
\hline
\end{tabular}

\section{Conclusions}

A fluorescence sensor was fabricated by modifying $\beta-C D @ A u N P s$ with NR for the trace detection of $\mathrm{NO}_{2}{ }^{-}$. The optional condition for the sensor was an acidic aqueous solution, and the detection limit was as low as $4.25 \times 10^{-3} \mu \mathrm{g} \cdot \mathrm{mL}^{-1}$. This sensor can selectively recognize $\mathrm{NO}_{2}{ }^{-}$through a visual color change from light purple or pink to light blue when the $\left[\mathrm{NO}_{2}{ }^{-}\right]$concentration is $0.30 \mu \mathrm{g} \cdot \mathrm{mL}^{-1}$. When $\left[\mathrm{NO}_{2}{ }^{-}\right]$exceeded $0.9 \mu \mathrm{g} \cdot \mathrm{mL}^{-1}$, the rate of fluorescence quenching reached $100 \%$, and the color changed. The sensor was applied to the detection of $\mathrm{NO}_{2}{ }^{-}$in local waters with a low detection limit, wide linear concentration range, good reproducibility, and anti-interference ability.

Supplementary Materials: The following are available online at www.mdpi.com/1424-8220/18/3/681/s1. Figure S1: (A) UV-Vis spectrum of AuNPs; (B) TEM image of AuNPs, Figure S2: (A) Emission spectra of NR (a) NR- $\beta$-CD@AuNPs (b) and NR- $\beta-C D(c)$; (B) TEM images of $\mathrm{NO}_{2}-\mathrm{NR}-\beta-C D$., Figure S3: The regression equation in a weakly alkaline (A) and an acidic medium (B)., Figure S4: (A) Emission spectra of NR in the presence of different $\left[\mathrm{NO}_{2}{ }^{-}\right]$, including $0,0.10,0.20,0.30,0.40,0.50$ and $0.60 \mu \mathrm{g} \cdot \mathrm{mL}^{-1}$. (B) Emission spectra of NR- $\beta-\mathrm{CD}$ in the presence of different $\left[\mathrm{NO}_{2}{ }^{-}\right]$, including $0,0.20,0.40,0.60,0.80,1.00,1.20,1.40$, and $1.6 \mu \mathrm{g} \cdot \mathrm{mL}^{-1}$. Table S1: Comparison of the fabricated sensor with other reported sensors for nitrite ions.

Acknowledgments: This work was supported by the Projects of Wenzhou Science and Technology Bureau (S20150012) and (W20170006), the Science Foundation of Zhejiang Province (LY13B040002), and the National Natural Science Foundation of China (No. 31300819).

Author Contributions: Weilu Zhang and Lizhu Yang conceived and designed the experiments. Xiaoyang Du performed the experiments and analyzed the data. Xiaoxia Zhang contributed the reagents and materials. Chunlai Jiang validated the experiments. Weilu Zhang and Xiaoyang Du wrote the paper.

Conflicts of Interest: The authors declare no conflict of interest.

\section{References}

1. Daniel, M.C.; Astruc, D. Gold nanoparticles: assembly, supramolecular chemistry, quantum-size-related properties, and applications toward biology, catalysis, and nanotechnology. Chem. Rev. 2004, 104, $293-346$. [CrossRef] [PubMed]

2. Saha, K.; Agasti, S.S.; Kim, C.; Li, X.; Rotello, V.M. Gold nanoparticles in chemical and biological sensing. Chem. Rev. 2012, 112, 2739-2779. [CrossRef] [PubMed]

3. Kelly, K.L.; Coronado, E.; Zhao, L.L.; Schatz, G.C. The optical properties of metal nanoparticles: The influence of size, shape, and dielectric environment. J. Phys. Chem. B. 2003, 107, 668-677. [CrossRef]

4. Rana, S.; Bajaj, A.; Mout, R.; Rotello, V.M. Monolayer coated gold nanoparticles for delivery applications. Adv. Drug Delivery Rev. 2012, 64, 200-216. [CrossRef] [PubMed]

5. Yang, X.; Yang, M.; Pang, B.; Vara, M.; Xia, Y. Gold nanomaterials at work in biomedicine. Chem. Rev. 2015, 115, 10410-10488. [CrossRef] [PubMed]

6. Sapsford, K.E.; Algar, W.R.; Berti, L.; Gemmill, K.B.; Casey, B.J.; Oh, E.; Stewart, M.H.; Medintz, I.L. Functionalizing nanoparticles with biological molecules: developing chemistries that facilitate nanotechnology. Chem. Rev. 2013, 113, 1904-2074. [CrossRef] [PubMed] 
7. Ray, P.C.; Fan, Z.; Crouch, R.A.; Sinha, S.S.; Pramanik, A. Nanoscopic optical rulers beyond the FRET distance limit: fundamentals and applications. Chem. Soc. Rev. 2014, 43, 6370-6404. [CrossRef] [PubMed]

8. Liu, C.W.; Lian, J.Y.; Liu, Q.; Xu, C.L.; Li, B.X. $\beta$-Cyclodextrin-modified silver nanoparticles as colorimetric probes for the direct visual enantioselective recognition of aromatic $\alpha$-amino acids. Anal. Methods 2016, 8, 5794-5800. [CrossRef]

9. Liu, J.; Lu, Y. Preparation of aptamer-linked gold nanoparticle purple aggregates for colorimetric sensing of analytes. Nat. Protoc. 2006, 1, 246-252. [CrossRef] [PubMed]

10. Deeb, C.; Zhou, X.A.; Gerard, D.; Bouhelier, A.; Jain, P.K.; Plain, J.; Soppera, O.; Royer, P.; Bachelott, R. Off-resonant optical excitation of gold nanorods: nanoscale imprint of polarization surface charge distribution. J. Phys. Chem. Lett. 2011, 2, 7-11. [CrossRef] [PubMed]

11. Stender, A.S.; Wang, G.F.; Sun, W.; Fang, N. Influence of gold nanorod geometry on optical response. ACS Nano 2010, 4, 7667-7675. [CrossRef] [PubMed]

12. Guo, S.J.; Wang, E.K. Synthesis and electrochemical applications of gold nanoparticles. Anal. Chim. Acta 2007, 598, 181-192. [CrossRef] [PubMed]

13. Serafin, V.; Eguilaz, M.; Agui, L.; Yanez-Sedeno, P.; Pingarron, J.M. An electrochemical immunosensor for testosterone using gold nanoparticles-carbon nanotubes composite electrodes. Electroanalysis 2011, 23, 169-176. [CrossRef]

14. Pingarron, J.M.; Yanez-Sedeno, P.; Gonzalez-Cortes, A. Gold nanoparticle-based electrochemical biosensors. Electrochim. Acta 2008, 53, 5848-5866. [CrossRef]

15. Dsouza, R.N.; Pischel, U.; Nau, W.M. Fluorescent dyes and their supramolecular host/guest complexes with macrocycles in aqueous solution. Chem. Rev. 2011, 111, 7941-7980. [CrossRef] [PubMed]

16. Yang, Y.W. Towards biocompatible nanovalves based on mesoporous silica nanoparticles. Med. Chem. Commun. 2011, 2, 1033-1049. [CrossRef]

17. Sun, Y.L.; Yang, B.J.; Zhang, X.A.; Yang, Y.W. Cucurbit [7] uril pseudorotaxane-based photo responsive supramolecular nanovalve. Chem. Eur. J. 2012, 18, 9212-9216. [CrossRef] [PubMed]

18. Mohanty, R.K.; Thennarasu, S.; Mandal, A.B. Resveratrol stabilized gold nanoparticles enable surface loading of doxorubicin and anticancer activity. Colloids Surf. B 2014, 114, 138-143. [CrossRef] [PubMed]

19. Palanisamy, S.; Sakthinathan, S.; Chen, S.M.; Thirumalraj, B.; Wua, T.H.; Loub, B.S.; Liuc, X.H. Preparation of $\beta$-cyclodextrin entrapped graphite composite for sensitive detection of dopamine. Carbohydr. Polym. 2016, 135, 267-273. [CrossRef] [PubMed]

20. Freeman, R.; Finder, T.; Bahshi, L.; Willner, I. $\beta$-cyclodextrin-modified CdSe/ZnS quantum dots for sensing and chiroselective analysis. Nano Lett. 2009, 9, 2073-2076. [CrossRef] [PubMed]

21. Wayu, M.B.; Schwarzmann, M.A.; Gillespie, S.D.; Leopold, M.C. Enzyme-free uric acid electrochemical sensors using $\beta$-cyclodextrin-modified carboxylic acid-functionalized carbon nanotubes. J. Mater. Sci. 2017, 52, 6050-6062. [CrossRef]

22. Du, D.; Wang, M.H.; Cai, J.; Zhang, A.D. Sensitive acetylcholinesterase biosensor based on assembly of $\beta$-cyclodextrins onto multiwall carbon nanotubes for detection of organophosphates pesticide. Sens. Actuators B Chem. 2010, 146, 337-341. [CrossRef]

23. Pourjavadi, A.; Eskandari, M.; Hosseini, S.H.; Nazari, M. Synthesis of water dispersible reduced graphene oxide via supramolecularcomplexation with modified $\beta$-cyclodextrin. Int. J. Polym. Mater. Polym. Biomater. 2017, 66, 235-242. [CrossRef]

24. Abbaspour, A.; Noori, A. A cyclodextrin host-guest recognition approach to an electrochemical sensor for simultaneous quantification of serotonin and dopamine. Biosens. Bioelectron. 2011, 26, 4674-4680. [CrossRef] [PubMed]

25. Chen, Y.; Liu, Y. Construction and function of cyclodextrin-based 1D supramolecular strands and their secondary assemblies. Adv. Mater. 2015, 27, 5403-5409. [CrossRef] [PubMed]

26. Guo, Y.Q.; Zhao, Y.M.; Lu, D.T.; Wu, H.J.; Fan, M.; Wei, Y.L.; Shuang, S.M.; Dong, C. $\beta-$ Cyclodextrin functionalized gold nanoparticles: Characterization and its analytical application for L-tyrosine. J. Inclusion Phenom. Macrocyclic Chem. 2014, 78, 275-286. [CrossRef]

27. Luo, C.H.; Zheng, Z.H.; Ding, X.B.; Peng, Y.X. Supramolecular assembly of $\beta$-cyclodextrin-capped gold nanoparticles on ferrocene-functionalized ITO surface for enhanced voltammetric analysis of ascorbic acid. Electroanalysis 2008, 20, 894-899. [CrossRef] 
28. Kodamatania, H.; Yamazakib, S.; Saitoc, K.; Tomiyasua, T.; Komatsud, Y. Selective determination method for measurement of nitrite and nitrate in water samples using high-performance liquid chromatography with post-column photochemical reaction and chemiluminescence detection. J. Chromatogr. A 2009, 1216, 3163-3167. [CrossRef] [PubMed]

29. Beamonte, E.; Bermudez, J.D.; Casino, A. A statistical study of the quality of surface water intended for human consumption near Valencia (Spain). J. Environ. Manag. 2007, 83, 307-314. [CrossRef] [PubMed]

30. Ito, K.; Takayama, Y.; Makabe, N.; Mitsui, R.; Hirokawa, T. Ion chromatography for determination of nitrite and nitrate in seawater using monolithic columns. J. Choromatogr. A 2005, 1083, 63-67. [CrossRef]

31. Zuo, Y.G.; Wang, C.J.; Van, T. Simultaneous determination of nitrite and nitrate in dew, rain, snow and lake water samples by ion-pair high-performance liquid chromatography. Talanta 2006, 70, 281-285. [CrossRef] [PubMed]

32. Zhang, H.; Qi, S.D.; Dong, Y.L. A sensitive colorimetric method for the determination of nitrite in water supplies, meat and dairy products using ionic liquid-modified methyl red as a colour reagent. Food Chem. 2014, 151, 429-434. [CrossRef] [PubMed]

33. Aydın, A.; Ercan, Ö.; Taşcıoğlu, S. A novel method for the spectrophotometric determination of nitrite in water. Talanta 2005, 66, 1181-1186. [CrossRef] [PubMed]

34. Wang, L.L.; Li, B.; Zhang, L.M.; Zhang, L.G.; Zhao, H.F. Fabrication and characterization of a fluorescent sensor based on Rh 6G-functionlized silica nanoparticles for nitrite ion detection. Sens. Actuators B Chem. 2012, 171-172, 946-953. [CrossRef]

35. Ojani, R.; Raoof, J.B.; Zarei, E. Electrocatalytic reduction of nitrite using ferricyanide; Application for its simple and selective determination. Electrochim. Acta 2006, 52, 753-759. [CrossRef]

36. Paixão, T.R.L.C.; Cardoso, J.L.; Bertotti, M. Determination of nitrate in mineral water and sausage samples by using a renewable in situ copper modified electrode. Talanta 2007, 71, 186-191. [CrossRef] [PubMed]

37. Lu, C.; Lin, J.M.; Huie, C.W.; Yamada, M. Chemiluminescence study of carbonate and peroxynitrous acid and its application to the direct determination of nitrite based on solid surface enhancement. Anal. Chim. Acta 2004, 510, 29-34. [CrossRef]

38. Pelletier, M.M.; Kleinbongard, P.; Ringwood, L.; Hito, R.; Hunter, C.J.; Schechter, A.N.; Gladwin, M.T.; Dejam, A. The measurement of blood and plasma nitrite by chemiluminescence: Pitfalls and solutions. Free Radic. Biol. Med. 2006, 41, 541-548. [CrossRef] [PubMed]

39. He, D.Y.; Zhang, Z.J.; Huang, Y.; Hu, Y.F. Chemiluminescence microflow injection analysis system on a chip for the determination of nitrite in food. Food Chem. 2007, 101, 667-672. [CrossRef]

40. Mikuška, P.; Večeřa, Z. Chemiluminescent flow-injection analysis of nitrates in water using on-line ultraviolet photolysis. Anal. Chim. Acta 2002, 474, 99-105. [CrossRef]

41. Mikuška, P.; Večeřa, Z. Simultaneous determination of nitrite and nitrate in water by chemiluminescent flow-injection analysis. Anal. Chim. Acta 2003, 495, 225-232. [CrossRef]

42. Zhang, T.; Fan, H.L.; Jin, Q.H. Sensitive and selective detection of nitrite ion based on fluorescence super quenching of conjugated polyelectrolyte. Talanta 2010, 81, 95-99. [CrossRef] [PubMed]

43. Singh, M.K.; Pal, H.; Koti, A.S.R.; Sapre, A.V. Photophysical properties and rotational relaxation dynamics of neutral red bound to $\beta$-cyclodextrin. J. Phys. Chem. A 2004, 108, 1465-1474. [CrossRef]

44. Mohanty, J.; Bhasikuttan, A.C.; Nau, W.M.; Pal, H. Host-guest complexation of neutral red with macrocyclic host molecules: Contrasting $\mathrm{pK}_{\mathrm{a}}$ shifts and binding affinities for cucurbit [7] uril and $\beta$-cyclodextrin. J. Phys. Chem. B 2006, 110, 5132-5138. [CrossRef] [PubMed]

45. Li, H.; Chen, D.X.; Sun, Y.L.; Zheng, Y.B.; Tan, L.L.; Weiss, P.S.; Wang, Y.Y. Viologen-mediated assembly of and sensing with carboxylatopillar [5] arene-modified gold nanoparticles. J. Am. Chem. Soc. 2013, 135, 1570-1576. [CrossRef] [PubMed]

46. Huang, T.; Meng, F.; Qi, L. Facile synthesis and one-dimensional assembly of cyclodextrin-capped gold nanoparticles and their applications in catalysis and surface-enhanced Raman scattering. J. Phys. Chem. C 2009, 113, 13636-13642. [CrossRef]

47. Zhao, Y.; Huang, Y.C.; Zhu, H.; Zhu, Q.Q.; Xia, Y.S. Three-in-One: Sensing, Self-Assembly, and Cascade Catalysis of Cyclodextrin Modified Gold Nanoparticles. J. Am. Chem. Soc. 2016, 138, 16645-16654. [CrossRef] [PubMed]

48. Eftink, M.R.; Ghiron, C.A. Anal Biochem, Fluorescence quenching studies with proteins. Anal. Biochem. 1981, 114, 199-227. [CrossRef] 
49. Liu, Y.L.; Kang, N.; Ke, X.B.; Wang, D.; Ren, L.; Wang, H.J. A fluorescent nanoprobe based on metal-enhanced fluorescence combined with Förster resonance energy transfer for the trace detection of nitrite ions. RSC Adv. 2016, 6, 27395-27403. [CrossRef]

50. Adarsh, N.; Shanmugasundaram, M.; Ramaiah, D. Efficient reaction based colorimetric probe for sensitive detection, quantification, and on-site analysis of nitrite ions in natural water resources. Anal. Chem. 2013, 85, 10008-10012. [CrossRef] [PubMed]

51. Chen, J.H.; Pang, S.; He, L.L.; Nugen, S.R. Highly sensitive and selective detection of nitrite ions using $\mathrm{Fe}_{3} \mathrm{O}_{4} @ \mathrm{SiO}_{2} / \mathrm{Au}$ magnetic nanoparticles by surface-enhanced Raman spectroscopy. Biosens. Bioelectron. 2016, 85, 726-733. [CrossRef] [PubMed]

52. Huang, X.; Li, Y.X.; Chen, Y.L.; Wang, L. Electrochemical determination of nitrite and iodate by use of gold nanoparticles/poly(3-methylthiophene) composites coated glassy carbon electrode. Sens. Actuators B Chem. 2008, 134, 780-786. [CrossRef]

(c) 2018 by the authors. Licensee MDPI, Basel, Switzerland. This article is an open access article distributed under the terms and conditions of the Creative Commons Attribution (CC BY) license (http://creativecommons.org/licenses/by/4.0/). 